\title{
The Effect of Yttrium Oxide Reinforcement on the Microstructural and Mechanical Properties of Biologically Derived Hydroxyapatite
}

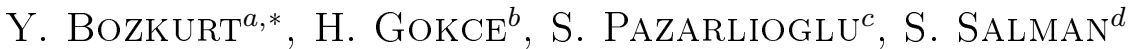 \\ ${ }^{a}$ Marmara University, Technology Faculty, Metallurgy and Materials Engineering Department, \\ 34722, Istanbul, Turkey \\ ${ }^{b}$ Istanbul Technical University, Prof. Dr. Adnan Tekin Material Science \& Production Technologies Applied \\ Research Center, 34469, Istanbul, Turkey \\ ${ }^{c}$ Marmara University, Technical Education Faculty, Metal Education Department, 34722, Istanbul, Turkey \\ ${ }^{d}$ Mehmet Akif Ersoy University, Faculty of Engineering \& Architecture, Mechanical Engineering Department, \\ 15100, Burdur, Turkey
}

\begin{abstract}
In the present study, hydroxyapatite used as a matrix material was derived from the femur bones of Meleagris gallapova (MGHA) and then reinforced with yttriyum oxide $\left(\mathrm{Y}_{2} \mathrm{O}_{3}, 5\right.$ and $\left.10 \mathrm{wt} . \%\right)$. Then samples pelleted at $350 \mathrm{MPa}$ were sintered between 900 and $1300{ }^{\circ} \mathrm{C}$. Finally, the effect of $\mathrm{Y}_{2} \mathrm{O}_{3}$ reinforcement on the microstructural and mechanical properties of MGHA was investigated. Scanning electron microscope (SEM) and X-ray diffraction (XRD) patterns were used for microstructural examinations. Density, microhardness and compressive strengths of composites were used to analyze their mechanical properties. Experimental results show that mechanical properties of composites were enhanced by increasing the temperature. The optimum results were obtained for MGHA$10 \% \mathrm{Y}_{2} \mathrm{O}_{3}$ composites sintered at $1200{ }^{\circ} \mathrm{C}$.
\end{abstract}

DOI: $10.12693 /$ APhysPolA.127.1403

PACS: 87.85.jf

\section{Introduction}

Hydroxyapatite $\left(\mathrm{Ca}_{10}\left(\mathrm{PO}_{4}\right)_{6}(\mathrm{OH})_{2}, \mathrm{HAp}\right)$ is one of the most bioactive and biocompatible materials and has been widely investigated as bone substitute and scaffold for hard tissue engineering. However, the low fracture strength and poor fatigue resistance due to the instability of $\mathrm{OH}^{-}$groups, limit the use of HA for load-bearing applications. Low mechanical properties of HA can be improved by precise control of the microstructure and the use of various reinforcements [1-4]. One of the most commonly used methods to improve the mechanical properties has been the production of HA-based composites, with reinforcements of oxide-based ceramics like yttria stabilized zirconia (YSZ), $\mathrm{Al}_{2} \mathrm{O}_{3}, \mathrm{ZrO}_{2}, \mathrm{TiO}_{2}$ or glass ceramics [5-7].

In the present study, we first obtained hydroxyapatite powders from the femur bones of Meleagris gallopova in three steps. Afterwards, Meleagris gallopova hydroxyapatite powders (MGHAp) were doped with yttria $\left(\mathrm{Y}_{2} \mathrm{O}_{3}\right)$ and sintered at $900,1000,1100,1200$ and $1300{ }^{\circ} \mathrm{C}$ for $4 \mathrm{~h}$ with the heating and cooling rates of $5{ }^{\circ} \mathrm{C} / \mathrm{min}$ in air atmosphere. Finally, the effect of sintering process and $\mathrm{Y}_{2} \mathrm{O}_{3}$ reinforcement on the microstructural and mechanical properties of MGHAp were investigated.

* corresponding author; e-mail: ybozkurt@marmara.edu.tr

\section{Experimental procedure}

\subsection{Materials}

In this study, hydroxyapatite powders used as matrix material were obtained from Meleagris gallopova femur bones, according to our early study [8], and reinforced with yttria (5 and 10 wt.\%, $\mathrm{Y}_{2} \mathrm{O}_{3}$ ). The powders of MGHA $(10 \mu \mathrm{m})$ and $\mathrm{Y}_{2} \mathrm{O}_{3}(5 \mu \mathrm{m})$ were well homogenized in Restch PM 100 ball milling device. Afterwards, green body pellets were compacted at $350 \mathrm{MPa}$ according to British 7253 standard [9]. Finally, the compacted green bodies were sintered at 900,1000,1100, 1200 and $1300{ }^{\circ} \mathrm{C}$ for $4 \mathrm{~h}$, with the heating and the cooling rates of $5^{\circ} \mathrm{C} / \mathrm{min}$.

\subsection{Mechanical properties}

Density of the sintered samples was measured by Archimedes method in distilled water. Theoretical density of the materials was calculated as $3.156 \mathrm{~g} / \mathrm{cm}^{3}$, $3.215 \mathrm{~g} / \mathrm{cm}^{3}$ and $3.277 \mathrm{~g} / \mathrm{cm}^{3}$ for MGHA, MGHA$5 \% \mathrm{Y}_{2} \mathrm{O}_{3}$ and MGHA-10\% $\mathrm{Y}_{2} \mathrm{O}_{3}$, respectively. Relative density of the materials was calculated comparing sintered densities with theoretical densities. The compression strengths of the sintered samples were measured using Devotrans universal testing device at speeds of $2 \mathrm{~mm} / \mathrm{min}$. Micro-vickers indentation method was used to determinate of the hardness of the sintered samples. Loads of $1.962 \mathrm{~N}$ for $20 \mathrm{~s}$ were applied to measure hardness. 


\subsection{Microstructural properties}

The XRD patterns were obtained at room temperature in an X'Pert MPD Philips diffractometer using $\mathrm{Cu}-\mathrm{K}_{\alpha}$ radiation in the range of $2 \theta\left(10-90^{\circ}\right)$. The microstructures of the samples were determined by scanning electron microscope (SEM, JOEL Ltd., JSM-5910 LV) after gold coating.

\section{Results and discussion}

XRD analysis results show that HA was detected for pure MGHA until $1100{ }^{\circ} \mathrm{C}$ without any second phase. However, at higher temperatures $\mathrm{HA}$ and also TCP (at $1200{ }^{\circ} \mathrm{C}$ ) and $\mathrm{HA}+\mathrm{TCP}+\mathrm{CaO}$ phases (at $1300{ }^{\circ} \mathrm{C}$ ) were detected as shown in Fig. 1a. $\mathrm{HA}$ and $\mathrm{Y}_{2} \mathrm{O}_{3}$ phases were detected for both MGHA-5Y and MGHA-10Y composites. However, at $1300{ }^{\circ} \mathrm{C}, \mathrm{HA}-\mathrm{Y}_{2} \mathrm{O}_{3}-\mathrm{TCP}-\mathrm{Y}(\mathrm{OH})_{3}$ (yttrium hydroxyde) and $\mathrm{Ca}_{3} \mathrm{Y}\left(\mathrm{PO}_{4}\right)_{3}$ (calcium yttrium phosphate) phases were detected for MGHA-5Y composites (Fig. 1b), while $\mathrm{HA}-\mathrm{Y}_{2} \mathrm{O}_{3}$ and TCP phases were detected for MGHA-10Y composites (Fig. 1c). These phases were also obtained in early studies [10-11].
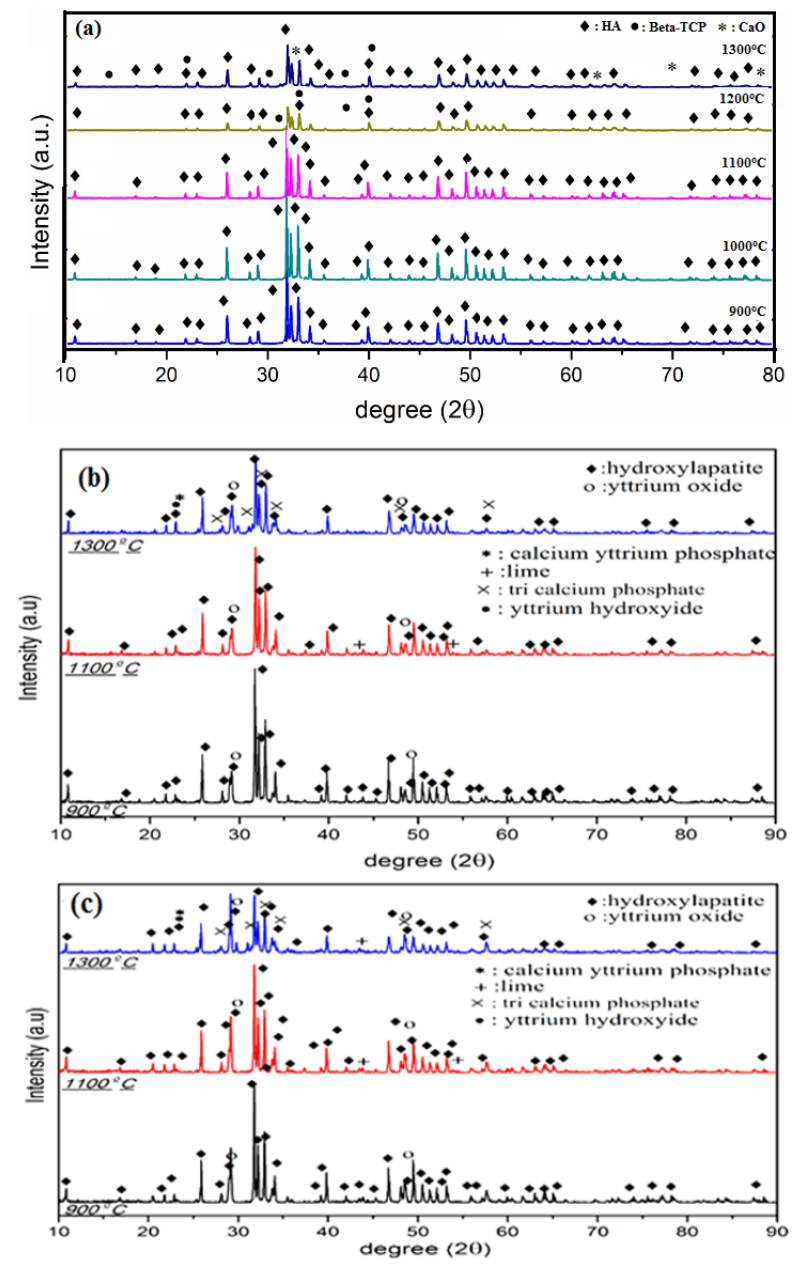

Fig. 1. XRD patterns of (a) pure MGHA, (b) MGHA$5 \mathrm{Y}$ and (c) MGHA-10Y composites.

In general, during solid state sintering of powder compacts, the pore size and morphology evolves through three stages: (i) an initial stage when necks start to form and grow between particles, (ii) an intermediate stage where tubular pores appear along the grain boundaries and (iii) a final stage at which the tubular pores break up into isolated quasi-spherical pores typically located at the triple points of grains [12]. When the pellets of MGHAp and MGHA- $\mathrm{Y}_{2} \mathrm{O}_{3}$ composites were sintered at $900{ }^{\circ} \mathrm{C}$, local interconnections between grains via necks and also large cavities due to open networks of pores were observed, as shown in Fig. 2a, 2b and 3a. During the intermediate sintering stage, not only the most of densifications has occurred, but also pore size, number, density of pores and pore morphology underwent significant changes. This event was determined for MGHAp and MGHA- $\mathrm{Y}_{2} \mathrm{O}_{3}$ composites sintered at $1100{ }^{\circ} \mathrm{C}$, as shown in Fig. 2c and Fig. 3b. In the final stage, no porosity was found on the surface of sintered samples at 1200 and $1300{ }^{\circ} \mathrm{C}$, as shown in Fig. 2d, 2e and 3c.
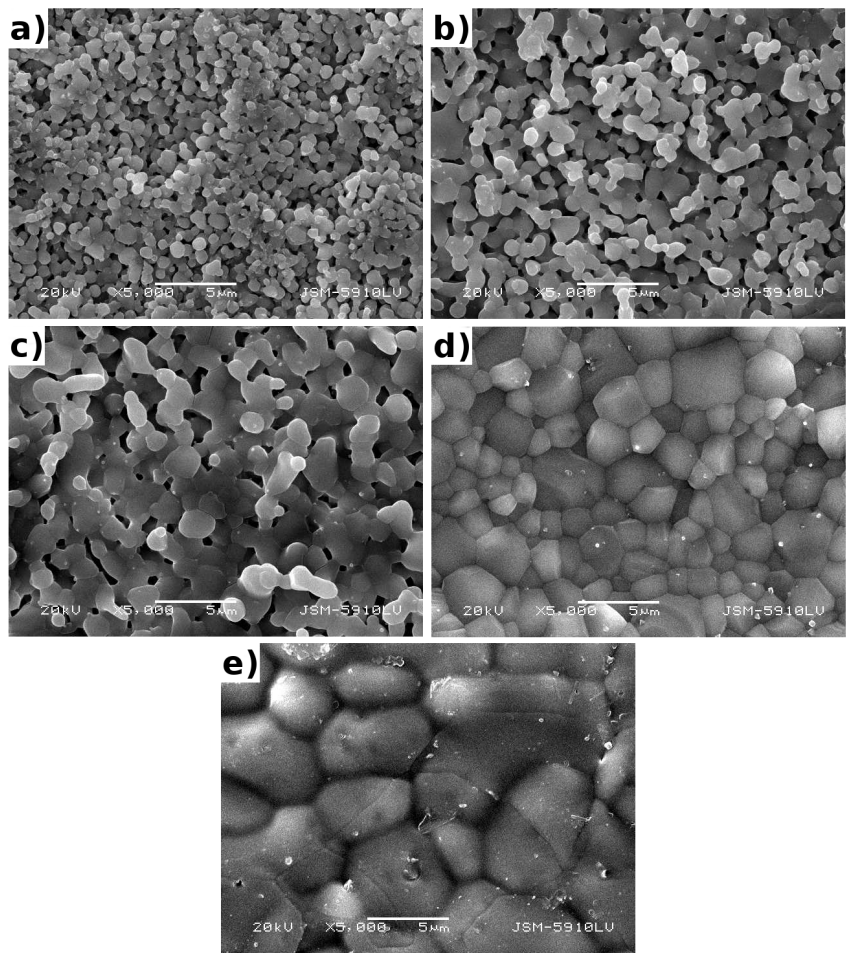

Fig. 2. SEM micrographs of MGHA sintered at (a) $900{ }^{\circ} \mathrm{C}$, (b) $1000{ }^{\circ} \mathrm{C}$, (c) $1100{ }^{\circ} \mathrm{C}$, (d) $1200{ }^{\circ} \mathrm{C}$ and (e) $1300{ }^{\circ} \mathrm{C}$.

As shown in Table, while the density and microhardness of the samples have increased at elevated temperature, the compressive strength of MGHA and MGHA$10 \mathrm{Y}$ have decreased at $1300{ }^{\circ} \mathrm{C}$, when compared to samples sintered at $1200{ }^{\circ} \mathrm{C}$. This situation may be related to much larger difference in the coefficients of thermal expansion (CTE) between the second (TCP) or third $(\mathrm{CaO})$ phases and the $\mathrm{HA}$, and also glassy phases sintered at $1300{ }^{\circ} \mathrm{C}$. The lowest density was obtained in MGHA$10 \mathrm{Y}$ sintered at $900^{\circ} \mathrm{C}$, the highest density was obtained 
in MGHA-10Y sintered at $1300{ }^{\circ} \mathrm{C}$. At lower temperatures and higher $\mathrm{Y}_{2} \mathrm{O}_{3}$ rates, lower density values were obtained from MGHA- $\mathrm{Y}_{2} \mathrm{O}_{3}$ composites. This can be explained by the fact that samples heat treated at lower temperatures were poorly sintered, as it is shown in SEM migrographs. However at higher temperatures and higher $\mathrm{Y}_{2} \mathrm{O}_{3}$ content, higher density values were obtained from MGHA- $\mathrm{Y}_{2} \mathrm{O}_{3}$ composites. This can be explain by the increase of diffusion rates of $\mathrm{Y}_{2} \mathrm{O}_{3}$ at higher temperatures and the effect of $\mathrm{Y}_{2} \mathrm{O}_{3}$ on the densification of MGHA. Hardness of the sintered ceramics is affected by average grain size, porosity rates and occurrence of the second and/or third phases. In the present study, microhardness values of sintered samples were increased by increasing sintering temperature and average grain sizes. In density measurements, the lowest and the highest microhardness values were obtained from MGHA-10Y for samples sintered at 900 and $1300{ }^{\circ} \mathrm{C}$, respectively. The slow increase of the hardness at $1300{ }^{\circ} \mathrm{C}$ compared to $1200{ }^{\circ} \mathrm{C}$ may be due to existence of closed porosity, increased grain size and/or formation of glassy phases around grains and the occurrence of new phases, as indicated by XRD analysis [13].

Compared to previous studies carried out with the HA powders derived from biological sources and then pelleted according to British 7253 standard density, microhardness and compressive strength of MGHAp are generally higher then those of the others [14-16]. These higher mechanical properties for $\mathrm{MGHA}-\mathrm{Y}_{2} \mathrm{O}_{3}$ may be related to the dissimilar average grain size of starting powders, calcination temperatures and times during the production of HA powders, ball milling time, number and diameters of balls, higher diffusion rate of $\mathrm{Y}_{2} \mathrm{O}_{3}$ into $\mathrm{HA}$ and due to reducing effect of $\mathrm{Y}_{2} \mathrm{O}_{3}$ on the transformation rates of HA into TCP. Experimental results also showed that MGHA- $10 \mathrm{Y}_{2} \mathrm{O}_{3}$ composites sintered at 1200 and $1300{ }^{\circ} \mathrm{C}$ can be used as a biomaterial for load bearing applications because of their high enough compressive resistance [17].

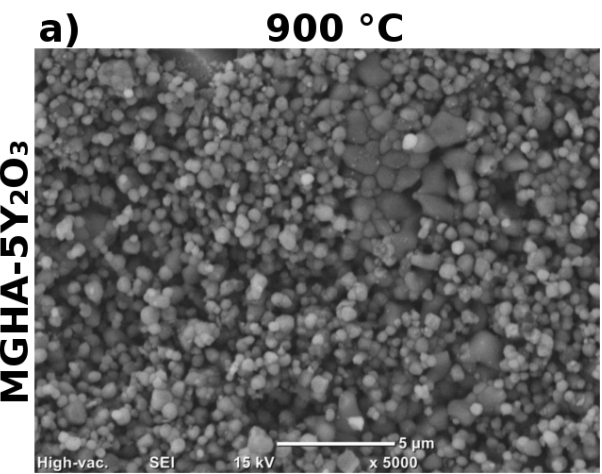

b)
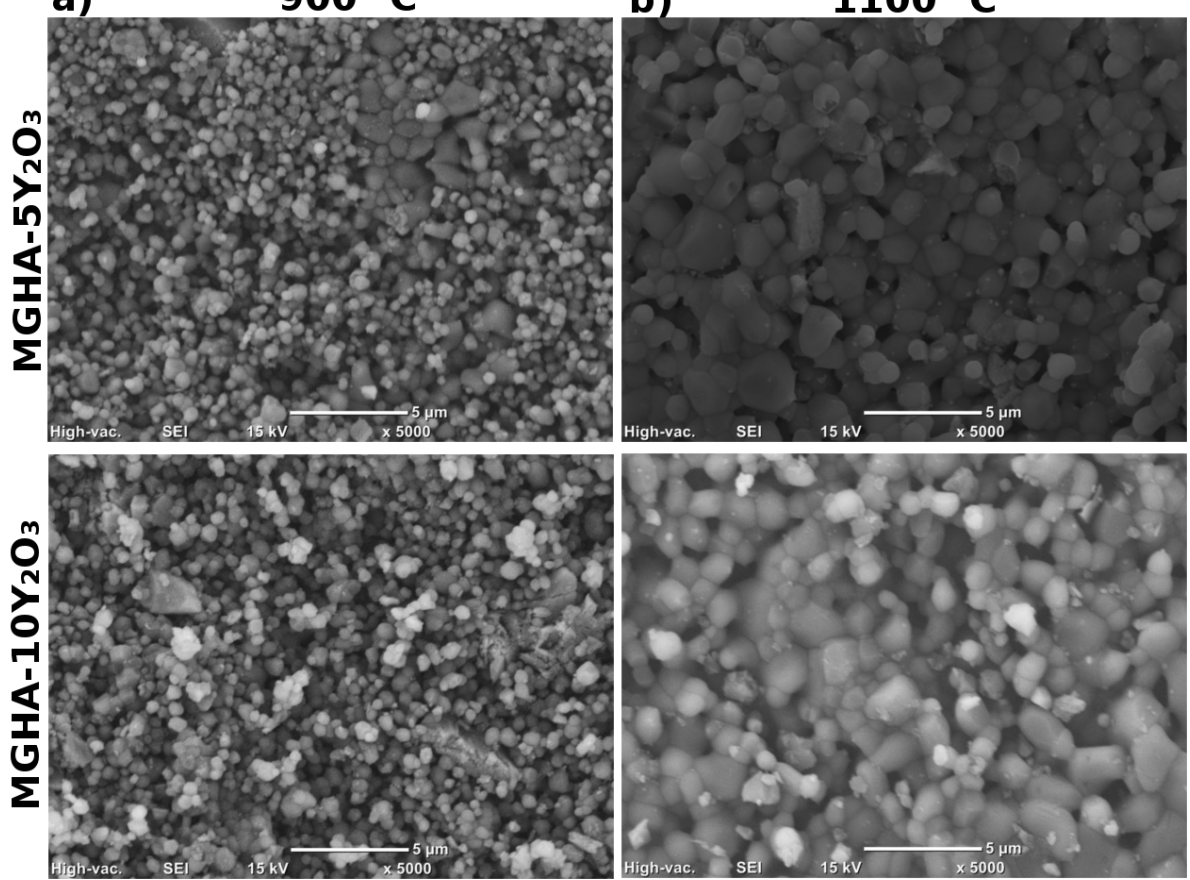

c)

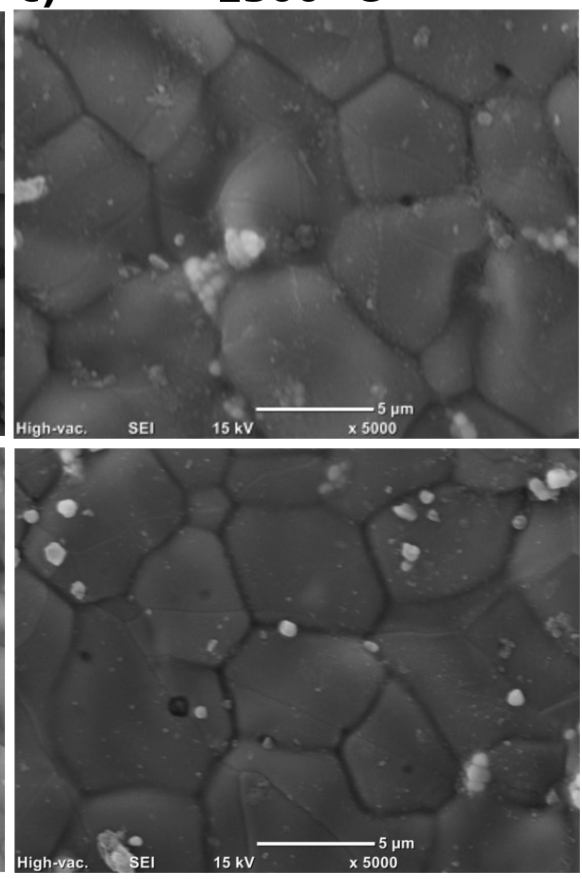

Fig. 3. SEM migrographs of MGHA- $\mathrm{Y}_{2} \mathrm{O}_{3}$ composites.

\section{Conclusion}

In this study, the influence of $\mathrm{Y}_{2} \mathrm{O}_{3}$ reinforcement on the microstructural and mechanical properties of MGHAp were investigated. The following conclusions can be drawn from the present study:

1. This study shows that mechanical properties of MGHAp can be improved by the reinforcement of $\mathrm{Y}_{2} \mathrm{O}_{3}$.
2. While the optimum sintering temperatures for MGHA and MGHA-10Y was found to be $1200{ }^{\circ} \mathrm{C}$, it was determined for MGHA-5Y to be $1300{ }^{\circ} \mathrm{C}$.

3. Higher mechanical properties were obtained at higher sintering temperatures.

4. MGHA- $10 \mathrm{Y}_{2} \mathrm{O}_{3}$ composites sintered at 1200 and $1300{ }^{\circ} \mathrm{C}$ can be used as biomaterial for load bearing applications. 
Mechanical properties of pure MGHA and MGHA- $\mathrm{Y}_{2} \mathrm{O}_{3}$ composites.

TABLE

\begin{tabular}{|c|c|c|c|c|c|c|c|c|c|c|c|c|}
\hline \multirow[t]{2}{*}{$\mathrm{T}\left[{ }^{\circ} \mathrm{C}\right]$} & \multicolumn{4}{|c|}{ MGHA } & \multicolumn{4}{|c|}{ MGHA-5Y } & \multicolumn{4}{|c|}{ MGHA-10Y } \\
\hline & $\begin{array}{l}\mathrm{d}_{\text {apparent }} \\
{\left[\mathrm{g} / \mathrm{cm}^{3}\right]}\end{array}$ & $\begin{array}{c}d_{\text {relative }} \\
{[\%]}\end{array}$ & $\begin{array}{c}\delta_{C} \\
{[\mathrm{MPa}]}\end{array}$ & $\mathrm{HV}$ & $\begin{array}{c}\mathrm{d}_{\text {apparent }} \\
{\left[\mathrm{g} / \mathrm{cm}^{3}\right]}\end{array}$ & $\begin{array}{c}\mathrm{d}_{\text {relative }} \\
{[\%]}\end{array}$ & $\begin{array}{c}\delta_{C} \\
{[\mathrm{MPa}]}\end{array}$ & $\mathrm{HV}$ & $\begin{array}{l}\mathrm{d}_{\text {apparent }} \\
{\left[\mathrm{g} / \mathrm{cm}^{3}\right]}\end{array}$ & $\begin{array}{c}\mathrm{d}_{\text {relative }} \\
{[\%]}\end{array}$ & $\begin{array}{c}\delta_{C} \\
{[\mathrm{MPa}]}\end{array}$ & $\mathrm{HV}$ \\
\hline 900 & 2.173 & 68.85 & 37.8 & 66.0 & 2.158 & 67.12 & 34.0 & 59.9 & 2.135 & 65.15 & 33.2 & 59.1 \\
\hline 1000 & 2.268 & 71.86 & 59.9 & 83.3 & 2.220 & 69.05 & 56.0 & 80.9 & 2.211 & 67.47 & 48.6 & 79.9 \\
\hline 1100 & 2.510 & 79.54 & 93.1 & 160.7 & 2.525 & 78.53 & 101.5 & 161.9 & 2.473 & 75.46 & 84.4 & 135.7 \\
\hline 1200 & 2.897 & 91.80 & 116.4 & 214.6 & 2.960 & 92.06 & 138 & 319.6 & 2.974 & 90.75 & 191.6 & 368.1 \\
\hline 1300 & 2.944 & 93.30 & 96.4 & 219.0 & 3.006 & 93.49 & 159.5 & 364.2 & 3.061 & 93.40 & 162 & 398.3 \\
\hline
\end{tabular}

\section{Acknowledgments}

The authors would like to thank Banvit Company (Izmir, TURKEY) for their support during experimental studies. This work was supported by the Scientific Research Project Program of Marmara University Project No: FEN-C-YLP-130313-0087.

\section{References}

[1] R. Sun, K. Chen, Z. Liao, N. Meng, Mat. Res. Bull. 48, 1143 (2013).

[2] J. Li, B. Fartash, L. Herrnansson, Biomaterials 16, 417 (1995).

[3] M.K. Herliansyah, M. Hamdi, A.I. Ektessabi, M.W. Wildan, J.A. Toque, Mat. Sci. Eng. C 29, 1674 (2009)

[4] G. Goller, F.N. Oktar, Mat. Lett. 56, 142 (2002).

[5] S. Kalmodia, S. Goenka, T. Laha, D. Lahiri, B. Basu, K. Balani, Mat. Sci. Eng. C 30, 1162 (2010).

[6] R. Ravarian, F. Moztarzadeh, M.S. Hashjin, S.M. Rabiee, P. Khoshakhlagh, M. Tahriri, Ceram. Int. 36, 291 (2010).

[7] H.B. Guo, X. Miao, Y. Chen, P. Cheang, K.A. Khor, Mat. Lett. 58, 304 (2004).
[8] S. Pazarlioglu, H. Gokce, S. Ozyegin, S. Salman, BioMed. Mater. Eng. 24, 1751 (2014).

[9] British Standard Non-metallic Materials for Surgical Implants, Specification for ceramic materials based on alumina BS 7253, Part 2, ISO 6474-1981, 1990.

[10] O. Gunduz, S. Daglilar, S. Salman, N. Ekren, S. Agathopoulos, F.N. Oktar, J. Comp. Mat. 42, 1281 (2008).

[11] A. Nakahira, K. Shiba, S. Yamaguchi, K. Kijima, Key Eng. Mat. 161-163, 177 (1999).

[12] X. Fan, E.D. Case, F. Ren, Y. Shu, M.J. Baumanni, J. Mech. Beh. Biomed. Mat. 8, 21 (2012).

[13] Y.W. Gu, N.H. Loh, K.A. Khor, S.B. Tor, P. Cheang, Biomaterials 23, 37 (2002).

[14] F.N. Oktar, L.S. Ozyegin, O. Meydanoglu, H. Aydin, S. Agathopoulos, G. Rocha, B. Sennaroglu, E.S. Kayali, Key Eng. Mat. 309-311, 101 (2006).

[15] F.N. Oktar, S. Agathopoulos, L.S. Ozyegin, O. Gunduz, N. Demirkol, Y. Bozkurt, S. Salman, J. Mater. Sci.: Mater. Med. 18, 2137 (2007).

[16] H.H. Celik, O. Gunduz, N. Ekren, Z. Ahmad, F.N.T Oktar, J. Biomat. Nanobiotech. 2, 98 (2011).

[17] L.L. Hench, An Introduction to Bioceramics, Second Edition, Larry L. Hench, p. 8, (2013). 